\title{
THE OXFORD HANDBOOK OF
}

\section{EARLY MODERN THEOLOGY, \\ $1600^{-1800}$}

Edited by

ULRICH L. LEHNER, RICHARD A. MULLER and

A. G. ROEBER 


\section{PROVIDENCE, \\ PREDESTINATION, AND \\ GRACE IN EARLY MODERN \\ CATHOLIC THEOLOGY}

THOMAS MARSCHLER

DEBATE over providence, predestination, and grace led Catholic theologians of the early modern period to formulations at once highly controversial and ingeniously constructive. The "grace controversy" between the Jesuit Molinists and the Dominican Báñezians was, according to Friedrich Stegmüller, "the most exciting and portentous event in the modern history of Catholic theology and at the same time the grandiose conclusion to a century churned up with religious ideas" (Stegmüller 1935, VII). The scene was set for these debates by the papal condemnations of the teachings of Michel Baius (1513-89) in 1567 and Cornelius Jansen the Younger (1585-1638) in 1653: the debates played out between the poles of a neo-Pelagian concentration on the claims of integral human nature before God, and the Augustinian concept of its utter dependence since the Fall on the operation of salvific grace.

\section{The Theological Connection between Providence, Predestination and Grace in Francisco Suárez, SJ}

Since the beginning of the sixteenth century, Catholic dogmatics has generally followed the order of Thomas Aquinas's (1225-74) Summa Theologiae. In his teaching on God in the Prima Pars, Thomas devotes one question each to providence and 
predestination (I, q. 22-23). The doctrine of grace is treated at length in the Prima Secundae (I-II, q. 109-14). The theologians of the early modern period retained these separate contexts for the discussion of the three topics while, however, emphasizing the connectedness of their subject matter and accentuating new aspects. This is exemplified in the disputations of the Jesuit Francisco Suárez (1548-1617). Suárez's teaching on God (1st ed. 1606), retains the close link between providence and predestination, but clearly shifts the emphasis in favor of the latter. While he offers only a brief section on providence at the end of the teaching on divine attributes (Suárez 1856-78, De deo uno 3.10 [I:231-35], he develops the topic of predestination in a separate treatise (Suárez 1856-78, De deo uno 3.10 [I:236-532]) which, set between the treatment of God's being and attributes and the treatise on the Trinity, constitutes one of the three main foci of his De deo uno et trino. In Suárez's view, after the Holy Trinity only predestination can be adjudged a strictly supernatural subject of scholarly reflection on God (Suárez 1856-78, De deo uno, Prooemium [I, XXIII]), the divine attributes and providence having been addressed in the metaphysical teaching on God (Suarez 1856-78, Disputationes metaphysicae 30.14-17 [XXVI:165-224]). Suárez's fundamental determinations of providence and foreordination initially operate within an area of consensus determined by the fathers, above all Augustine. By "providence" he understands God's plan for the entire universe, which unfolds as God guides the whole as well as every particular toward the goals he intends for them (Marschler 2013, 32-40). He ascribes great importance to the distinction between "natural" and "moral" providence: the former applies to all creatures and includes the conservation of being granted by God and the divine concursus in all creaturely activity; the latter concerns only angels and human beings to the extent that they are beings who pursue the goal of their existence in freedom. It finds expression in "commandments, words of advice, promises, threats, rewards and punishments" (Suárez 1856-78, De deo uno 3.10.7 [I:232b]), thus pointing beyond philosophical deliberation to the sphere of free divine acts of revelation. Providence is an expression of God's sovereign and just dominion but also of his goodness and wisdom. Knowing and willing conjoin in its constitution (Suárez 1856-78, De deo uno 3.10.10 [I:233b]).

In his freedom, God decided to open up a goal to rational creatures, transcending the capacity of their nature as established in creation and orienting them towards eternal life (Suárez 1856-78, De praedestinatione 1.1.6 [I:237b]; 1.4.5 [I:243b]). In God this goal is presupposed from all eternity as a certain determination, whereas according to the doctrine of the Council of Trent (Denzinger and Hünermann 2010, 1540.1565-66), it normally remains hidden from the creature (Suárez 1856-78, De praedestinatione 1.3.5 [I:240a]). Since in predestination the path, the necessary means by which the goal can be reached, and the goal itself are fixed (Suárez 1856-78, De praed. 15.5.15 [I:248b), predestination can be regarded as part of providence (on the more exact definition of the relationship, see Suárez 1856-78, De praed. 1.15 [1:305a-309b]). This points to the supernatural dimension of providence, thus enabling a (theological) solution to many difficult problems (for example, the suffering of many of the just on earth) (Suárez 1856-78, De deo uno 3.10.14 [1:234b]). Predestination, however, takes into 
consideration the aspect of the choice of goal, whereas providence is oriented more towards obtaining the right means of reaching it (Suárez 1856-78, De praed. 15.5.17 [I:249a]).

Alongside the question of how, on God's part, intellect and will work together in the act of predestination, the theological schools asked how this certain goal of human existence can be reconciled with the unimpaired reality of creaturely freedom. This topic links the treatises on predestination and grace. If grace (understood as gratia creata) is the means through which God makes possible the orientation and election of created beings to eternal life during their earthly existence, the relationship of grace to predestination is like that of created, temporal effects to their uncreated, eternal cause (Suárez 1856-78, De praed. 1.19 [I:309b-313b]). Accordingly, the independent treatise de gratia deals with God in his activity of sanctification and illustrates central attributes of God from the perspective of their manifestation in salvation history (Suárez 1856-78, De gratia, Prooem. [VII, p. IX-X]), Suárez's teaching on grace has also been considerably developed beyond Aquinas's text. Originally filling three folio volumes, this is the most elaborate of Suárez's theological works (Scorraille 1917, 2:377).

Suárez begins with six detailed prolegomena in which he treats systematic and historical presuppositions of his topic. 'The first two parts, on free will as the "foundation of grace $^{n}$ (Suárez 1856-78, De gratia, no. 7 [VII, p. XI-XII]) and on divine foreknowledge, point toward controversial questions of the times. The subsequent division of the treatise according to actual and habitual grace (Suárez 1856-78, De gratia, lib. I-V/VI-XI), the roots of which lie in the fourteenth century but are now theologically differentiated and consolidated, continued to shape the Catholic treatise on grace until well into the twentieth century. Whereas the major questions de auxiliis are discussed in the first part (the need for divine grace in the natural and supernatural spheres, the distinction between sufficient and efficacious grace in the interplay with human freedom), the second section contains the thorny debates about justification, the nature of salvific grace and merit, and the final perseverance of the recipient of grace, classifying them as problems already present in the texts of the Council of Trent.

The publication history of Suárez's De gratia illustrates the explosive nature of debates on the theology of grace at the beginning of the seventeenth century. In the last years of his life, the Jesuit had sought permission in Rome to be allowed to publish his work De auxiliis. In April 1617, a few months before his death, a letter reached him written by Cardinal Scipione Borghese in the name of the pope, forbidding the publication (Scorraille 1917, 2:234f.). Whereas the first and third volumes of Suárez's teaching on grace were published soon after his death in 1619 , it was over three decades before the third part, De auxiliis, also became publicly available in Lyons in $\mathbf{1 6 5 4}$ as a result of a private initiative and without the consent of the Jesuit Order (Scorraille 1917, 2:398ff). Thus even Suárez was not able to escape the strict ruling of the decree of August 28, 1607, a dilatory decision by Paul V (1552-1621) that put an end to inconclusive disputations concerning the compatibility of God's grace with human freedom. It was not until the Jansenist debates of the mid-seventeenth century that this decision, supported by a "decree of the Inquisition of 1 December 1611 forbidding all further writings on the 
doctrine of grace unless they were expressly authorized by the Holy Office" (Pastor 1927, 180 ), was gradually relativized.

\section{The Central Positions in the "Grace Controversy"}

The "grace controversy" which unfolded following the publication of the Dominican Domingo Báñez's (1528-1604) commentaries on the Prima and Prima Secundae (Salamanca 1584) and the Jesuit Luis de Molina's (1535-1600) "Concordia liberi arbitrii cum gratiæ donis, divina præscientia, providentia, prædestinatione et reprobatione" (Lisbon 1588) went on for two decades (see the overview in Stegmüller 1960). We examine the theological alternatives that were debated in the Disputationes de auxiliis.

\subsection{The common theological foundation}

The competing theses of the theological schools in the field of providence, predestination, and grace can only be correctly classified if one bears in mind the shared framework of theological premises within which they were expressed. The theology of Augustine served as an undisputed basis which was never questioned, not even in the arguments with the Reformers. The debates de auxiliis were in large part a struggle for interpretational hegemony in the exegesis of Augustine's texts. Thus the terms of reference for all the schemes included the doctrines of original sin; infallible predestination; the necessity, gratuity and priority of grace; and the conviction that God does not move man merely "extrinsically" with his grace but also (and predominantly) "intrinsically." Taken over from medieval Scholasticism and deepened were both the metaphysical analysis of gratia (interna) creata and the thesis of the essentially supranatural character of grace and of the theological virtues. From the sixteenth century onward, theology had to face up to a new challenge from the reformers' theology of grace, above all from Luther's concept of freedom, his theses on the preparation and nature of justification or on the assurance of salvation, and also from Calvin's doctrine of predestination. The answers given in the Council of Trent's 1547 Decree on Justification constituted for all Catholic authors the authoritative template for the tracts on grace. Against Luther, the conviction was defended that original sin did not completely destroy man's ability to produce morally good acts even without divine grace. Since, however, the Council of Trent had taught that even those justified by God required the help of a "special grace" in order to persevere in the good (Denzinger and Hünermann 2010, 1541.1572), doubt was raised concerning the sinner's ability to perform good deeds on a permanent and unqualified basis. Subtle debates were conducted on the exact extent of the remaining freedom for good (for example, in fulfilling the requirements of natural law) and its dependence on 
divine assistance. This already touches on the central issue of the early modern theology of grace: how is the relationship between divine grace and human freedom to be determined? In the following we shall try to shed light on the two most important attempts at an answer.

\subsection{Báñezian Thomism}

There is one fundamental theological-metaphysical conviction at the heart of the theology of grace put forward in the seventeenth century Thomist school since Domingo Báñez: God is the cause of every motion and change in the universe, not only because he is the "unmoved mover" at the beginning of creation, but also because he subsequently enables and supports every action of his creatures. The human will is no exception. When it transitions from potency to act, it requires a cause for the determination that is thereby accomplished (Alvarez 1611, 64f; Garrigou-Lagrange 1936, 51 et passim). The will's dependency on God for being and motion exemplifies the esse ab alio as the fundamental determination of every created being (as distinct from the divine actus purus) (Alvarez 1611, I.9, disp. 96 [763]). This causal premotion, which is more than a mere moral stimulus on God's part, is called by the Thomists praemotio/praedeterminatio physica. Initially controversial, these terms were accepted in the course of the debate, even as being synonymous (Hübener 1989). God's eternally established sovereignty, which manifests itself in the causal prae of his willing and acting towards creation, is particularly visible in the supernatural sphere. Creaturely freedom can only orient itself to its eternal goal if it is antecedently elevated; that is, made capable of such acts by God himself. The distinction between efficacious and (merely) sufficient grace cannot, according to the Thomist model, be determined "extrinsically" through the decision of the creature, but must come ab intrinseco, from God's grace itself. God is in no way dependent on the creature - not even on the level of his own foreknowledge of the creature's free decisions. This makes it clear how man's free collaboration with the divine impulse of grace is to be understood. It cannot possibly be a matter of combining two "competing" partial causes. Rather, God and free will are each to be regarded as total causes, albeit on two levels which must be strictly separated from one another: God is the primal cause, human freedom the secondary (and thus at the same time immediate) cause of all the acts it performs: as itself human freedom effects that which God has in advance made it capable of (Alvarez 1611, I.9, disp. 98 [779f]): “to 'predetermine' ... means nothing other than to cause the will to determine itself; as physically premoving the free will means nothing other than bringing about truly effectively, through an inwardly approaching motion, that this will moves itself" (Alvarez 1611, I.9, disp. 91 [731]). As Aquinas taught, God moves all things in accordance with their nature: natural things in a natural manner, free ones in keeping with their freedom (Alvarez 1611, I.3, disp. 18-23 [138-233]). Thus God's moving the free will towards himself as the highest good does not inflict any coercion on the human being, even as it defines the doctrine of predetermination: God alone can be the inner motive principle of the human will; even 
the angels and demons, as the highest created powers, can only ever influence man's will from outside.

This basic metaphysical-theological principle resulted in a particular understanding of human freedom (Alvarez 1611, I.12, disp. 115 [914-22]). It rejects the Molinist definition that regards free will as presupposing all the factors necessary for acting; namely, the capacity to act or not to act or to do either one thing or another. For the Thomists, the combination of the determining factors of "presence of all the necessary prerequisites for acting" with "indeterminateness" is an unacceptable contradiction. In their opinion, the praerequisita ad operandum include the causal predetermination of the will to concrete action (in the context of the theology of grace, through God's efficacious grace). The capacity of willing does not "simultaneously" (in sensu composito) possess the indifference also to do the opposite. This indeterminateness can only be admitted in sensu diviso: the will could, in a differently determined act, also do the opposite of what it has now decided to do. The Thomists see this as satisfying the insistence of the Council of Trent that the human being receiving the call to God's grace can also resist it (Alvarez 1611, I.9, disp. 92 [743f]). Behind this lies a highly intellectualized definition of freedom that sees its innermost ground as lying in the indifference of practical reason toward all finite goods, which as such are incapable of unequivocally determining a will that is orientated towards the good in general.

Freedom is the capacity of the will and of reason to realize in action one of two possibilities or to refrain from acting. Although freedom subsists formally in the will as its proximate and immediate subject, with respect to its roots and foundations it nevertheless lies in the intellect. For it is founded and rooted in the indifference of the judgement through which the intellect judges that an object, which the will imagines must be loved, does not possess a necessary or natural connection with the universal good to which the will is naturally orientated, that is, as regards its specification. (Alvarez 1611, I. 9, disp. 92, no. 7 [918])

The directly determined will remains free in its roots to the extent that this indifference in judging is preserved, even when the will has committed itself with an action. And when God as the highest good fixes the will in himself, the unique case arises that the human being is relieved through grace of the otherwise insurmountable tension between the infinite reaching of the will and the finite choice of goods that cannot satisfy it. God binds the will to himself as the infinite good, which means that human striving can come to rest even though for the creature the certainty of this rest is not the result of seeing it directly but only the perception in faith shaped by love. "Not being able to resist this, indeed not even being able to desire to, is no impairment of freedom but rather its fulfilment" (Ramelow 1997, 49). Thus in one crucial point those given grace on earth already resemble those given bliss in heaven, whose freedom is not decreased, but rather perfected, by no longer being able to turn away deliberately from God. For the Thomists, the doctrine of the physical predetermination of the will is the crucial argument for God's being able in his decree to foresee with certainty from all eternity man's 
free decisions and, on the basis of this knowledge, to direct the world according to his plan. If God's grace enables human beings to act (as he intends), it becomes superfluous to ask whether these plans can be thwarted by the creature's resistance.

Although the Thomist approach is convincing in its systematic coherence, it is burdened with three closely related problems. One is formulated in the question of why God, in view of his role as universal mover, cannot also be regarded as the direct originator of human sin. Is the withholding of efficacious grace not responsible for a human being not repenting, in other words sinning? The problem seems to be exacerbated by the fact that leading Thomists equate this refusal of grace with a "blinding" or "hardening" of the sinner by God. Admittedly, they do add by way of explanation that the unwillingness of the human being himself remains the true cause of his failure to repent. God is in no way obliged to put an end to this state of affairs through his gift of grace. This refusal can be explained with the doctrine of original sin; but then at the very least the sin of the first human being still remains in need of an explanation.

The second query points to the possibility of distinguishing between sufficient and efficacious grace, a distinction that seems to be canceled in the Thomist system. Alongside a grace that is of itself infallibly successful, one that is conditionally efficacious is in danger of becoming a meaningless concept-since apart from God there is not supposed to be any cause that could actualize the mere possibility of sufficiency (Alvarez 1611, I.9, disp. 102 [808-13]). The Thomists' sufficient grace does from a human perspective contain an objectively real but subjectively unattainable potential; it lies within the power of the sinner only to deny himself this, thus making it ineffective. From God's perspective it belongs on the plane of a willing that has never really been realized (the voluntas antecedens as opposed to the voluntas consequens), the relevance of which can be doubted.

Third and finally, it remains unclear whether the Thomist approach is able to do adequate justice to the biblical teaching of God's universal salvific will. If divine predestination points to an absolute decree, the enforcement of which takes place by means of an infallibly efficacious gift of grace, the rejection of certain people seems likewise to have to be ascribed to a positive act of will on God's part from all eternity (Alvarez 1611, I.11, disp. 109 [856]). This, too, is not performed conditionally by God (referring to a person's foreseen demerit or refusal), but absolutely (Alvarez 1611, I.11, disp. 110 , no. 9 [866]). For the rejected, the lack of grace is thus to be considered the formal effect of divine reprobation for which no cause is to be discerned beyond the divine will (on the background, see Stiglmayr 1964). Critics have always seen there to be a great danger of this view leading to the concept of double predestination. The Thomists themselves point to the insoluble mystery of the co-existence of divine mercy and justice:

The fact that of two people who are preveniently moved by the same movement of grace one consents and cooperates with the grace, decides on a pious act and is converted, whereas the other persists in sin, cannot be ascribed to the pure, naturally indwelling, specific and interior freedom common to both the good and the bad, the 
reprobate and the elect; instead, the fact that one is converted must be ascribed to the absolute and efficacious decree of God, who wanted in his mercy to convert him and meet his needs with the effective help of his preveniently efficacious grace, whereas he [God] justly left the other in the mass of perdition with the help of merely sufficient grace. (Alvarez 1611, I.9, disp. 97 [774])

Whether the "strict Thomists" of the seventeenth century actually renewed or falsified the pure teaching of the Doctor angelicus with their system of grace was a matter of contentious dispute for centuries. Since the end of neo-Thomism as the ideal in Catholic theology shortly after Vatican II (1962-65), it has become easier to acknowledge the newness of the emphases introduced by Báñezianism:

In a strange interpenetration of the Thomist idea of order (the ordo universalis must be realized in the display of God's mercy and justice; paradoxically even the permitting of evil serves this ordo), Scotist Voluntarism (determining goals or aims before means; explaining predestination through the "ab aeterno" of the divine, absolutely efficacious willing; according to the Bánezians election and reprobation are indeed acts of the intellect, but presuppose an act of will) and the thinking of St Augustine, which still takes its bearings from Holy Scripture (Jacob and Esau in their grace or reprobation represent a type of all election or rejection), an election is taught that precedes any decision on the part of the creature (praedestinatio ante praevisa merita). (Stiglmayr 1964, 159f)

The Thomists after Vincent Contenson (1641-74) themselves clearly moderated the teaching on the restriction of sufficient grace, as is already apparent in the theology courses of the Salmanticenses and then in Billuart (1658-1757) (Flynn 1938). Alongside a recognition of the objective problems of the thesis, this probably came about as a result of the Jansenist controversy and the doctrinal concessions of the congruist Molinists (Stiglmayr 1964, 162-67).

\subsection{Molinism}

"Molinism" is, as research over the past hundred years has shown, undoubtedly even more of a problematic catch-all term than "Bánezianism". "If a Molinist is understood to be someone who agreed with all of Molina's theses, then there were no Molinists except Molina," is Klaus Reinhardt's hyperbolic comment (Reinhardt 1965, 241). Thus the concept remains usable only as a vague general term that brackets together certain majority theses within Jesuit theology since the end of the sixteenth century on how to determine the relationship between divine grace and creaturely freedom. It has long since been established that the historical origins of these theses are not to be associated exclusively with Molina's name and that the teachings of his Concordia were considerably modified by the Jesuits in subsequent decades (see already Lurz 1932, 36.218). 
The undisputed fundamental conviction of the seventeenth-century Jesuit school is the rejection of a physical predetermination of human freedom by a God issuing universally effective decrees in both the natural and supernatural spheres. In their definition of freedom, Molinists claim what was rejected by the Thomists: "That agent is called 'free' who, with all the prerequisites for acting having been posited, is able to act and is able not to act, or is able to do one thing in such a way that he is also able to do some contrary thing" (Molina 1953, p. 1, disp. 2, n. 3 [14, I:8ff]). If creaturely freedom has to be defined as an underivable and spontaneous capacity for self-determination that is incompatible not merely with coercion but also with necessity, then it cannot-either in its actual enactment or in the determination therein fulfilled-be traceable completely to a causal impulse from God. This option has been seen as the translation of the decision-centered practice of Ignatian spirituality into theology (Reinhardt 1965, 219), but even more as an attempt to effectively defend the Catholic dogma against the Lutheran concept of servum arbitrium. Philosophically, Molina builds on Scotus (Molina 1953, p. 1, disp. 24, n. 8 [157]). Like him, Molina denies neither the necessity of the concursus Dei generalis nor the need for divine grace in order for supernatural acts to come about. He confirms the antecedence of God's gracious action, taken in the Augustinian sense of the interna vocatio Dei (God's internal calling) directed to man's intellect and will, and also affirms man's inability to bestow a supernatural quality on his acts by his own freedom. But at the same time Molina is convinced that God never wants to bypass human freedom with his gracious action. As a rule, God does not give someone an inner vocation if that person has not previously been reached by the Church's proclamation of the faith (Molina 1953, p. 1, disp. 9, n. 4-6 [45]); and the prevenient grace only becomes effective as a moral impulse when the assent of the human will is present. If, therefore, of two people to whom the Gospel has been preached one repents and the other does not, this must not be attributed to the inefficacy of the grace as such, because grace is not "the sole and complete cause of assent to faith" (Molina 1953, p. 1, disp. 12, n. 1 [56, I:17]). Rather, the prevenient grace approaching the human being from outside and our free decision to collaborate with it work together as two parts of a universal cause in the one indivisible supernatural act; it is only our analytical minds that make a distinction between them. This is where Molina's famous metaphor belongs of the "two pulling a ship" (Molina 1953 , p. 2, disp. 26, n. 15 [170, I:30]): our free consent or cooperation is the reason for the difference between efficacious as opposed to sufficient grace (Molina 1953, p. 3, disp. 40, n. 11-12 [249f]); conversely, it is the creature's refusal that prevents the supernatural act from coming about.

Molinism attempts to explain how, given these premises, one can speak of a predestination by God that is one from all eternity with the foreknown efficacy of his grace. Molina developed this over the two decades preceding the publication of the Concordia, at about the same time as his confrère Pedro de Fonseca (1528-99). The crucial element is that he approaches it from God's foreknowledge. Alongside the "natural-necessary" knowledge that applies to everything in God's power (irrespective of its realization) and the "free" knowledge that refers to what is actually existing and arises from God's decrees, Molina here distinguishes a third form, namely "middle knowledge": "With 
this, God, with his supreme and inscrutable knowledge of the essential being of every free will, has seen what this [i.e., free will] would do according to its inherent freedom if it were to find itself in this or that order or even in an infinite number of orders of things even though it could, on the other hand, if it so wished, actually do the opposite" (Molina 1953, p. 4, disp. 52, n. 9 [540]). God knows in advance certainly and infallibly, together with the free decrees of his will, all the possible contingent circumstances determined by free actions of creatures (free secondary causes) -including those that are never in fact realized. This implies a prior vision of the free decisions of creatures that takes place in these circumstances.

Among the preconditions of creaturely acts are the external or internal impulses of grace received from God. But although God foreknows under what conditions certain human beings will cooperate with grace and obtain merits, he does not declare the merits to be the cause of God's infallible predestination. "The foreseen merits are not the medium propter quod but the medium per quod et sine quo non. The infallibility of predestination lies not in the nature of the graces but rather in God's foreknowledge" (Reinhardt 1965, 188f). On the basis of his antecedent knowledge of the possible worlds and the actions of the creatures in them, God freely decides by a universal decree in favor of a single real world, whose course he can survey and in which his gifts of grace are so attuned to the conditionally foreseen free decisions of the creatures that his goals will be achieved. 'The concept of 'possible worlds' undoubtedly expanded the speculative scope of the possible. However, in its actual function, it served to speculatively reduce the scope of the practical possibilities that human freedom opens up and to make them readily comprehensible-for God and for the philosopher who wants to understand the conditions pertaining to the possibility of divine freedom in knowledge and action" (Ramelow 1997, 47). The further discussion of Molina's solution inside and outside the Jesuit school highlights some of the difficulties that confronted his theses. Thomists saw the scientia media hypothesis as doomed to failure in its attempt to safeguard God's certain knowledge of the free acts of human beings without physical predetermination, since in view of the contingency of the causes, the truth value of statements about something conditionally future remains uncertain. What cannot be called true "with certainty" could, with Aristotle, be qualified as not knowable (even by God) (Alvarez 1611, I.2, disp. 7, n. 17 [8of]). While Molina expressed himself clearly in favor of an indeterminateness of the future contingents because he saw this as being the only way of guaranteeing human freedom, after him a growing majority of Jesuits affirmed "the fixed truth value of singular propositions about future contingents" (Knebel 1991, 270), employing more strongly nominalist explanations side by side with realistically oriented ones (Reinhardt 1965, 104-27; Ramelow 1997, 93-123). What proved even more complicated was the question of the medium of God's cognition in the case of his "middle knowledge." Basically, the theologians were faced with the possibility of contemplating an either extra-divine or inner-divine medium quo (Lurz 1932, 84-116; Reinhardt 1965, 132-44). If an eternal existence of things "beside" God is excluded, the contingent future events themselves can be considered a possible medium of knowledge. In taking this path, which was pioneered by some Nominalists, 
one is again confronted with the uncertain truth value of propositions concerning it and its possible dependence on divine knowledge itself. If, on the other hand, one attempts to ground the scientia media in God's knowledge of the creaturely secondary causes that bring it about, it can be objected that either it would have to be possible to deduce their free decisions with certainty from the circumstances of their acts (which would amount to a deterministic reduction of freedom; Garrigou-Lagrange 1936,68 ), or that they enable God to make a (perhaps very good, but never certain) prognosis only of the probability of their future acts. Gregory of Valencia (1549-1603) tried to solve the problem with the novel thesis of a preparatory and virtual independent decision on the part of the human will, which God could know in advance as regards the concrete decision (Hentrich 1928). Speculations as to God's insight into the "moral necessity" to which decisions of the human will may be subject remained popular among other Jesuits of the time (Knebel 2000 , $190 \mathrm{ff}, 223 \mathrm{f}$ and passim). In the second major paradigm for a solution that points to a medium of knowledge within God in order to illustrate his apprehension of the futura conditionata, the recourse to the will of God is excluded for the opponents of strong predefinition models. Consequently, only God's essence can be assumed to be the medium to the extent that it causes the reality of the creature or (merely) makes it knowable for God as in a mirror. Molina had been thinking along these lines when he pointed to the "divine intellect's unlimited power of representation vis-à-vis its object," to God's supercomprehensio, through which "the knowledge of a contingent object [becomes] ex parte subjecti necessary knowledge" (Ramelow 1997, 228). Many later Jesuits continued with this approach and modified it; Antonio Pérez (1599-1649) and Martin Esparza (1606-89), for example, speak of an "intentional pre-existence" of the conditional truths in the divine eternity (Ramelow 1997, 202f, 222f). But does this path lead out of the circular argument that arises when a creature's assent to divine grace is meant to provide the ground for conditional knowledge of this assent and thus also for the actual gift of grace, whereas at the same time it is divine grace in the first place that makes the real existence of the creature's assent possible, and this in turn is ontologically identical with the conditional assent on which the scientia media depends (Knebel 1991, 279, n. 100)? In the end, all that is left is to speak of (with Bernaldo de Quiros and Aldrete) is a mutua causalitas (Ramelow 1997, 262), which sets out rather than resolves the problem. This, too, proved incapable of refuting the charge that a predestination constructed with the help of scientia media calculations radically neutralizes what is proper to creaturely freedom because it makes the biographies of free creatures look in God's eternal knowledge like abstractly definable ideas. When, shortly before the middle of the seventeenth century, the Suárez school campaigned for the existence-repudiated by Molina himself-of a scientia media reflexa, in which God also knows prospectively how he will possibly act given conditional future events, theological discourse turned more and more into planning a strategy, conceived on God's behalf, with the aim of immunizing his providential plans as skillfully as possible against all "disruptions" on the part of creaturely freedom (Ramelow 1997, 263-69). It did not escape the notice of the opponents of this expansion of the theory that assuming God's knowledge of his own decrees before he 
issued them threatened to stifle not only creaturely but also divine freedom in calculations of necessity (Ramelow 1997, 266f).

A second main objection from the Thomists had accused Molina's approach of bringing God into a problematic dependency relationship vis-à-vis his creatures, in that his predestination was seen as a reaction to (albeit hypothetical) free decisions on the part of these creatures (Alvarez, I.12, disp. 121, n. 2 [960]). In fact, the Jesuit had taken into account the "overall balance" of God's middle knowledge with respect to his decision in favor of one of the countless possible worlds, and had thus made the predestination of the individual, which occurs together with the choice of a certain order, logically coordinate or subordinate to God's foreseeing of his merits. This line of argument was pursued explicitly by the Jesuit Leonardus Lessius (1554-1623) in his treatise on grace, first published in 1610 . This book provoked major controversies within the Society of Jesus, the course of which has been documented in detail by Xavier-Marie Le Bachelet (Le Bachelet 1931). Lessius's most important critics within his own order were Robert Bellarmine (1542-1621) and Francisco Suárez with their own model of grace, which was later called "Congruism". Aquaviva (1543-1615), the general of the order, soon also joined in the argument over Lessius's book, as did several leading Dominican theologians. In 1611 it spread as far as Pope Paul V, who feared a rekindling of the recently concluded debates De auxiliis. Despite all the hostility, Lessius scarcely departed from his core theses. On December 14, 1613, Aquaviva put an end to the controversy with his practical, not speculatively oriented decree that obliged all Jesuits to adhere to the Congruist thesis (Le Bachelet 2:236-45). His influence is to be seen among leading Jesuits such as Arriaga (1592-1667), Tanner (1572-1632), or Ruiz de Montoya (1562-1632). Through the republication of his book on grace (1626), Lessius himself also maintained a presence in the ongoing debate up to and beyond his death in 1623 . Aquaviva's decree was never formally revised, but in practice decreased in relevance as the contexts of the discussion changed (Le Bachelet 2:382-85).

The crucial difference between strict Molinism and Congruism lies in the fact that the latter speaks of a distinction between sufficient and efficacious grace in actu primo by giving strictly intrinsic, not extrinsic reasons for the efficacy of grace. God distributes his graces in a targeted manner and does not "scatter them around" (Ramelow 1997, 275), because he knows for whom the power of these gifts, which is sufficient for everyone, will in fact actually become effective. He brings into reality the world that he has foreseen as possible qua scientia media and in which precisely those achieve salvation whom he determined for this, prior to their merits (ante praevisa merita). This distinction took account of the criticism of the Dominicans, who, in Augustinian tradition, strictly rejected a reason for predestination in man, as well as the reference from within their own order to General Borja's 1565 Ratio Studiorum (Reinhardt 1965, 219ff). For the Congruists, God's original praedilectio thus achieves the same effect on a human being through a moral influence as the physically efficacious grace of Thomism. As Knebel has pointed out, in the Congruist calculation human decisions made under the influence of grace, as God apprehends them in advance in his scientia media, are treated in a fairly standardized, atomized, and serial manner, being seen mechanistically almost like the 
output of "supernatural mass production" (Knebel 2000, 172; Knebel 2007, 15f). From this there evolved a praxis model with a "completely means-end rationality" (Knebel 1991, 290). Although the pluralization of the Congruist scientia media calculation led in some authors to a renewed desire for a synthesizing meta-reflection-as documented, for example, in Antonio Pérez's concept of a scientia media universalissima (Ramelow 1997, 90-93) - the concentration on the individual case nevertheless remains evident. The formal unconditionality of individual freedom remains constant throughout the course of every action and is, according to God's providential plan, guided through a finite sequence of concrete decision-making situations in such a way that in the end the goal intended by God is reached. Only the idea of a creatura rebellis that rejects every divine grace in all possible worlds remains a problem that even the subtlest Congruist scheme finds hard to eliminate. It is here that we get the clearest confirmation of the thesis boldly formulated by individual Jesuits that God has given his omnipotence into the hand of our free will (Knebel 2000, 186, n. 262, pointing to passages in Izquierdo and Mauro).

Over the course of time there have been clear changes in the verdicts on whether the continuity rather than the difference between Molina and Suarez should be emphasized, and whether the road from one to the other is to be regarded as one of progress or decline from the original scientia media. The older Jesuits pursued a noticeable interest in playing down the differences between Molinism and Congruism (see, e.g., Schneemann 1881), and the increasing convergence between the Society of Jesus and the Thomist tradition was even accounted by some interpreters to be "the greatest progress in the history of Molinism" (Lurz 1932, 223). In more recent times, however, the "moral-external" determination of man in Congruism and the "physical-intrinsic" in Thomism have quite frequently been categorized as equally problematic attacks on human freedom-combined with the call for consideration to be given to fundamentally new ways of explaining the relationship between nature and grace (Greiner 2011).

\section{A Brief Retrospective}

The early modern struggle over grace and predestination has-like the Scholasticism of the period as a whole-received largely negative, at times almost pitying assessments in later times. It has been seen as the sad squandering of great intellectual potential, a getting bogged down in frightful subtleties and proof of an inability to be innovative in crossing the narrow boundaries of a paradigm that offered nothing more to discuss. The neo-Thomism of the early twentieth century attempted to unveil Molina as nothing less than the forefather of the "anthropological turn" that reached its zenith in Kant; whereas the Jesuits tried in a similarly one-sided manner to emphasize Molina's fidelity to Aquinas. With the rise in twentieth-century Catholic theology of a subject- and freedom-oriented way of thinking, the Molinist heritage was generally rated considerably more highly, whereas Báñezian Thomism has found hardly any defenders. Down to the most recent debate on the analytical philosophy of religion, Molinism has remained 
present as an option to be taken seriously, albeit leaving out the theological dimension of grace (Perszyk 2012).

Undeniably, Molinism aims at a separation between a natural structure in which God can intervene at any time and a sphere of creaturely freedom that is inviolable even for God, and to which he only has access through the back door of his prior knowledge. The unique nature of the esse morale is discovered and celebrated here, but at the same time the groundwork is laid for the modern diastasis between nature and freedom, which manifests itself definitively in Kant. In his important research, Knebel has pointed to further connections that have crossed over, often unrecognized, from the Jesuit school into modern philosophy. In the treatise on grace, for example, the beginnings are to be found of the optimism debate so central for Leibniz, as well as the development of highly complex discourses on a "statistical paradigm of moral necessity" (Knebel 2000, 275486; Ramelow 1997, 123-30), with which the essentially unfathomable factual truth that grace-filled people do sin is made rationally comprehensible. Linked with the concept of moral necessity is a pointer "to the fact that the world also works reliably in the realm of events that are dependent on the free will" (Knebel 2000, 557); that is, it is rationally predictable. The scientia media hypothesis attempts in this way to resolve the problem, which had been virulent since Scotus and unavoidable for Aristotelian-type epistemology, of how to reconcile creaturely contingency with the theological discourse on necessity (Knebel $2007,17 \mathrm{f}$ ). Even though it would hardly be likely to make any sense to present the whole of modern philosophical thinking as a reception history of the Báñezian-Molinist disagreements (against Ocaña Garcia 2000), the above-mentioned points of contact with the early modern doctrine of grace have ensured the continued interest in it by philosophical interpreters right down to the present day, whereas scarcely any notice is taken of it in contemporary theology.

\section{BIBLIOGRAPHY}

Álvarez, Diego, OP. 1611. De auxiliis divinae gratiae et humani arbitrii viribus et libertate. Lyon. Báñez, Domingo, OP. 1614. Scholastica commentaria in primam partem Doctoris Angelici $D$. Thomae usque ad sexagesimam quartam quaestionem complectentia. Douai.

Denzinger, Heinrich, and Peter Hünermann, eds. 2010. Kompendium der Glaubensbekenntnisse und kirchlichen Lehrentscheidungen/Enchiridion symbolorum definitionum et declarationum de rebus fidei et morum. 43rd ed. Freiburg: Herder.

Garrigou-Lagrange, Réginald. 1936. "Prémotion physique." In Dictionnaire de Théologie Catholique, vol. XIII/1, 31-77. Paris: Letouzey.

Greiner, Michael. 2011. "Gottes wirksame Gnade und menschliche Freiheit. Wiederaufnahme eines verdrängten Schlüsselproblems." In Theologische Anthropologie, edited by Thomas Pröpper, vol. 2, 1351-1436. Freiburg: Herder.

Flynn, Leo. 1938. Billuart and his Summa Sancti Thomae. London.

Hentrich, Wilhelm. 1928. Gregor von Valencia und der Molinismus. Innsbruck: Rauch.

Hübener, Wolfgang. 1989. "Praedeterminatio physica." In Historisches Wörterbuch der Philosophie, vol. 7, 1216-1225. Basel: Schwabe. 
Knebel, Sven K. 2007. "Einleitung zu: Diego del Mármol S. I., Tractatus de auxilio efficaci divinae gratiae, ec eius cum libero arbitrio creato concordia." In Die scholastische Theologie im Zeitalter der Gnadenstreitigkeiten, edited by Ulrich L. Lehner, vol. 1, 9-54. Nordhausen: Bautz.

Knebel, Sven K. 1991. "Scientia media: Ein diskursarchäologischer Leitfaden durch das 17. Jahrhundert." Archiv für Begriffsgeschichte 34: 262-294.

Knebel, Sven K. 2011. Suarezismus. Erkenntnistheoretisches aus dem Nachlass des Jesuitengenerals Tirso González de Santalla, 1624-1705: Abhandlung und Edition. Amsterdam: B. R. Grüner.

Knebel, Sven K. 2000. Wille, Würfel und Wahrscheinlichkeit. Das System der moralischen Notwendigkeit in der Jesuitenscholastik, 1550-1700. Paradeigmata 21. Hamburg: Meiner.

Le Bachelet, Xavier-Marie. 1931. Prédestination et grâce efficace. Controverses dans la Compagnie de Jesus au temps d'Aquaviva, 1610-1613. 2 vols. Louvain: Museum Lessianum.

Lurz, Wilhelm. 1932. Adam Tanner SJ ( + 1632) und die Gnadenstreitigkeiten des 17. Jahrhunderts. Breslau: Müller \& Seiffert.

Marschler, Thomas. 2013. "Verbindungen zwischen Gesetzestraktat und Gotteslehre bei Francisco Suárez im Begriff der lex aeterna." In Auctoritas omnium legume: Francisco Suárez' "De Legibus" zwischen Theologie, Philosophie und Jurisprudenz, edited by Oliver Bach, Norbert Brieskorn, and Gideon Stiening, 27-51. Stuttgart and Bad Cannstatt: Frommann-Holzboog.

Molina, Luis de, SI. 1953. Concordia liberi arbitrii cum gratiae donis, divina praescientia, providentia, praedestinatione et reprobatione, ad nonnullos primae partis $D$. Thomae articulos, edited by Johannes Rabeneck. Oniae: Collegium Maximum.

Ocaña García, Marcelino. 20oo. Molinismo y libertad. Córdoba: Publ. Obra Social y Cultural Cajasur.

Pastor, Ludwig von. 1927. Geschichte der Päpste im Zeitalter der katholischen Restauration und des Dreißigjährigen Krieges: Leo XI und Paul V (1605-1621). Freiburg: Herder.

Perszyk, Ken, ed. 2012. Molinism: The Contemporary Debate. Oxford: Oxford University Press.

Ramelow, Tilman. 1997. Gott, Freiheit, Weltenwahl: Die Metaphysik der Willensfreiheit zwischen A. Perez SJ (1599-1649) und G. W. Leibniz (1646-1716). Brills Studies in Intellectual History 72. Leiden, New York and Köln: Brill.

Reinhardt, Klaus. 1965. Pedro Luis SJ (1538-1602) und sein Verständnis der Kontingenz, Praescienz und Praedestination. Portugiesische Forschungen der Görres-Gesellschaft, Zweite Reihe, Bd. 2. Münster: Aschendorff.

Schneemann, Gerhard. 1881. Controversiarum de divinae gratiae liberique arbitrii concordia initia et progressus. Freiburg: Herder.

Scorraille, Raoul deSJ. 1917. El P. Francisco Suárez de la Compañia de Jesús. 2 vols. Barcelona: Subirana.

Stegmüller, Friedrich. 1935. Geschichte des Molinismus I: Neue Molinaschriften. Münster: Aschendorff.

Stegmüller, Friedrich. 1960. "Gnadenstreit." In Lexikon für Theologie und Kirche. 2nd ed., vol. 4, 1002-1007. Freiburg: Herder.

Stiglmayr, Emmerich. 1964. Verstoßung und Gnade. Die Universalität der hinreichenden Gnade und die strengen Thomisten des 16. und 17. Jahrhunderts. Roma: Herder.

Suárez, Francisco, SJ. (1856-1878). Opera omnia. 28 vols. Paris: Vivès. 